\title{
THE HYBRIDIZATION OF THE NOIR GENRE AS EXPRESSION OF ETHNIC HERITAGE: RAFAEL NAVARRO'S SONAMBULO
}

\author{
ANNA MARTA MARINI \\ Universidad de Alcalá de Henares - Instituto Franklin \\ annamarta.marini@gmail.com
}

Received 24 August 2020

Accepted 2 June 2021

\section{KEYWORDS}

Comics; film noir; horror film; supernatural; Mexican American; wrestling; folktale; identity; US minority; US-Mexico border

\section{PALABRAS CLAVE}

Cómics; film noir; cine de terror; sobrenatural; cultura mexicoamericana; lucha libre; leyenda; identidad; minorías estadounidenses; frontera

\begin{abstract}
In his ongoing comic book series Sonambulo, versatile artist Rafael Navarro has been able to channel his Mexican American cultural heritage by creating a unique blend of narrative genres. In his work, Navarro exploits classic American film noir as a fundamental reference and hybridizes it with elements distinctive to a shared Chicanx heritage, such as lucha libre cinema, horror folktales, and border-crossing metaphors; the construction of an oneiric dimension helps bring the narrative together, marking it with a peculiar ambiance. Drawing heavily on a diverse range of film genres, as well as ethnocultural pivots, this comic book series carves out a definite space in the panorama of the Mexican American production of popular culture, adding a powerful voice to the expression of US ethnic minorities.
\end{abstract}

\section{RESUMEN}

En su serie de cómic Sonambulo, el versátil artista Rafael Navarro ha conseguido canalizar su herencia cultural mexicoamericana, creando una mezcla única de distintos géneros narrativos. En su obra, Navarro toma el cine negro clásico estadounidense como referencia fundamental y la hibrida a través de elementos peculiares de una herencia chicana compartida, como por ejemplo el cine de luchadores, leyendas de terror, y metáforas del cruce fronterizo; la construcción 
de una dimensión onírica ayuda la armonización narrativa, creando una atmosfera distintiva. Inspirándose en una variedad de géneros cinematográficos, así como en pivotes etnoculturales, la serie forja un espacio definido en el panorama de la producción mexicoamericana de cultura popular, añadiendo una voz poderosa a la expresión de las minorias étnicas en los Estados Unidos.

Born in the border town of Nogales and raised in Los Angeles, where he has been based since, Rafael Navarro has built a fruitful career as illustrator, storyboard artist for widely known US TV animated shows ${ }^{1}$ and independent comic book creator. The products of his work have been as diverse as his personal interests, ranging from film to literature (Navarro in Aldama, "Your Brain" 225). In 1988 he began to work as a freelance penciller for mainstream comic book publishers such as DC Comics, Marvel, and Dark Horse (ibid 224), as well as in the field of animation, cultivating the idea of producing his own independent, self-published comics. A keen comic book reader himself, Navarro felt the need to create a character that would open a space he felt was missing in the industry; a space in which could fit genres, tropes, and styles whose blending would come across as unexpected, especially by a Mexican American author. Since 1996, Navarro's quest has been condensed in his ongoing comic book series Sonambulo ${ }^{2}$, shaping a peculiar hybrid genre that could be defined as lucha-noir, as it blends most tropes characterizing classic American film noir - a genre often characterized by its intrinsic whiteness (Lott 546) - and fundamental elements of the Mexican American cultural heritage, such as horror folktales, lucha libre, and heteroglossia (Aldama, "Your Brain" 67).

The exploitation of Mexican American folktale tropes has been touched on as well by various artists-such as for example Navarro's longtime friend Javier Hernandez, in his ongoing comic book series $E l$ Muerto-and likewise others have exploited Mexican myths and

\footnotetext{
1 Among many, it is worth mentioning Daytime Emmy award-winning Tutenstein (PorchLight Entertainment, 2003-2008), Rugrats (Nickelodeon, 1991-2004), and lucha libre-themed iMucha Lucha! (Warner Bros., 2002-2005).

2 The series is composed, so far, of two 3-issue long arcs (Sleep of the Just 1996; Mexican Stand-Off 2004-2006), two standalone issues (Ghost of a Chance 2002; Sonambulo Lives! 2009), issues collecting short stories and/or with the collaboration of fellow comics creators (Sonambulo's Strange Tales 2000; Masks of Sonambulo 2003), participations in anthologies (such as "The One That Got Away" 2006). At the present date, a new Sonambulo issue is in the works, composed by short stories written by different authors and drawn by Navarro.
} 
cosmogony, a notable example of which is Rhode Montijo's Pablo's Inferno (2000). It is worth reminding-albeit briefly-that in the 80s Chicanx creators such as, chiefly, the Bros. Hernandez, managed to create longstanding comic book series in which ethnically diverse, slice-of-life stories intertwined with sci-fi subgenres, introducing Latinx perspectives and themes, shaping and nurturing the panorama of Chicanx alternative comics (among many, see Merino; Garcia). Still, genres such as noir seem to be hardly considered as "authentically" Latinx, somehow limiting the possibilities of expression of the creators and possibly circumscribing them to selected, allegedly heritagerelevant themes. Nonetheless, an analysis of Sonambulo's diegetic pivots demonstrates that hybridized noir can be an effective tool to convey precisely the expression of US ethnic minority heritage.

Interweaving textual and visual references deriving from his personal background, Navarro has created a unique comic book series, laced with his own Mexican American identity. As he expressed through a short bio/graphic narrative (Navarro, "Mi Voz" 155), bringing forth his culture, as well as his personal perspective on it, he began to share his own, unique voice. A voice that is intrinsically Mexican American, as the spelling of the title character's name-as well as the occasional usage of Spanglish in dialogues, or the simplification of Spanish spelling-reveals: Sonambulo is neither a sonámbulo nor a sleepwalker, he is his own hybrid identity. The fundamental elements are well-defined and structured, creating a peculiar genre, allowing Sonambulo to find its own liminal place/space between lucha, noir tradition, and supernatural horror. Infused with Mexican American heritage themes, an articulated oneiric dimension brings Navarro's fictional world together, in a formula-defying product that reconfigures the boundaries of American alternative comics.

\section{LUCHA-NOIR: A CHARACTER TORN BETWEEN NOIR TRADITION AND LATINX CULTURAL HERITAGE}

The protagonist of Navarro's series is Salomon Lopez, a man of Mexican origins who used to be a renowned luchador in the heyday of lucha libre, wrestling under the name of Sonambulo and living the life of a successful and beloved performer. Nonetheless, when pressed by the local mob, he did not accept to abide by their requests, faithful to his own moral code; he was consequently beaten up, shot, and left for dead. However, Sonambulo simply fell into a deep sleep that lasted for decades and from which he happens to wake up in present times, 
adapting himself and starting a new life as a private detective in Los Angeles. The uncanny sleep he had fallen into has left him cursed: on the one hand he seems to be unable to sleep ever again, while on the other, he acquired the ability to read the dreams of others. Through dreams, Sonambulo can fathom people's fears, hopes, and memories, entering an oneiric dimension he is accustomed to and in which he often faces his own ghosts. The private eye finds himself dealing with cases that involve supernatural entities, getting entangled in suspenseful, quirky adventures. Among the fundamental themes characterizing the comic book series, the iconography and tropes related to Mexican lucha libre are embodied by the mask its eponymous protagonist invariably wears. If that is certainly the most evident lucha element at first sight, Sonambulo's stories are disseminated with wrestling details and the construction of the character is solidly based on a distinctive lucha-inspired ethos.
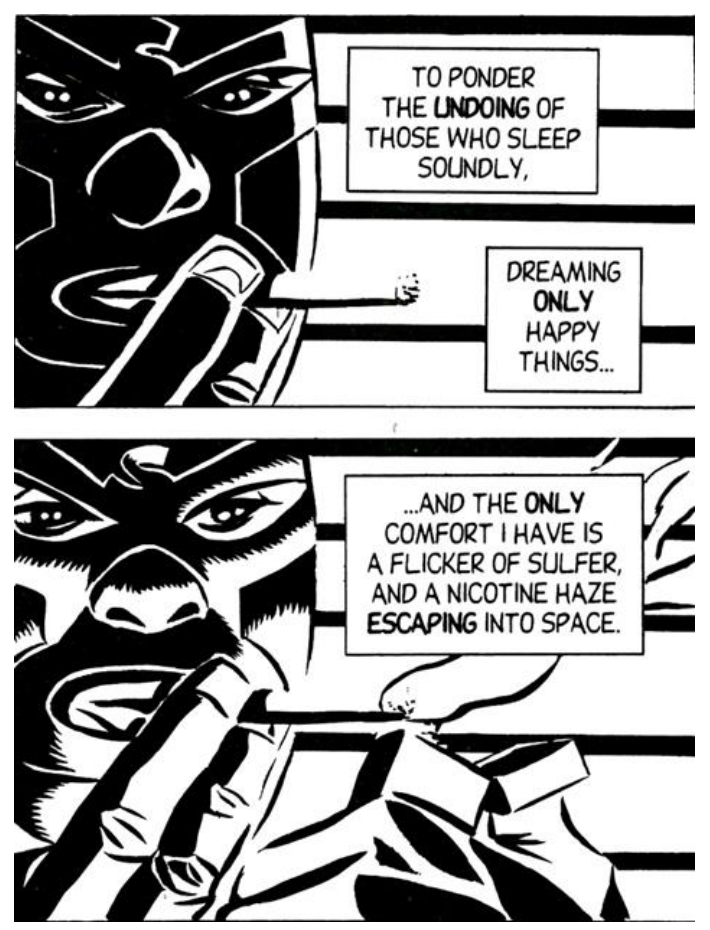

Figure 1 Sonambulo: Strange Tales, 1. 
Sonambulo is marked by a definite noir ambiance, a feature the author highlights as essential and encompassing the nuances and foreboding darkness of classic film noir (Navarro, "Tell Him Your Dreams"). It is worth noting that Navarro is a keen cinephile, and his passion for black and white films-ranging from Italian neorealism to Mexican época de oro cinema-is evident (ibid.; Navarro in Aldama, "Your Brain" 228). In that regard, his inspirations can be traced in the cinematographic quality pervading his panels throughout the whole series, and in the Sleep of the Just arc (1996) ${ }^{3}$ in particular. In comics, paradigms distinctive of the noir genre have been exploited by series such as, among others, Frank Miller's renowned-and crudely violent-Sin City (1991-2000), as well as zoomorphic Blacksad (Diaz Canales and Guarnido, 2001-2013), sexploitation-driven Black Kiss by Chaykin (1988-1989), Brubaker and Phillips' The Fade Out (20142016), and the notable Will Eisner's The Spirit (1940) and Torpedo 1936 (1981-2000) by Sánchez Abuli and Bernet. From film noir, Sonambulo draws the archetypic private detective as a protagonistremindful of hardboiled literary characters-as well as the presence of music, stark black and white aesthetics, non-linear narratives, nightmarish plots and criminal motives.

Classic American film noir-as it will be analyzed further onemerged in the early 40s and was characterized by the reconstruction of criminal adventures, usually happening in grimy urban settings and suffocating interiors, marked by a sense of bleakness, cynicism, and moral ambiguity. Despite its representation of social tensions and recurrent focus on working class characters, the genre seemed to obliterate the existing conflicts related to ethnicity and remain exempt of critique in such regard. In most noir films, the represented otherness is constructed around moral boundaries rather than cultural or racial, revolving around the "'dark' side of the white Western self" (Lott 543). Later on, African American filmmakers-such as Spike Lee-have appropriated and interpreted classic noir moods to enrich Black film, exploiting the capability intrinsic to film noir to express social criticism and thereby question the normalcy of existing social structures (for a thorough study, see Flory). Nonetheless, the genre in its classic configurations seems to still lack a Latinx perspective, despite its potential possibilities.

\footnotetext{
${ }^{3}$ All page references that will be made to the Sleep of the Just arc from now on will refer to the collected edition (2001).
} 
It is worthwhile noting the existence of a few films set on and across the US-Mexico border, or directly involving Mexican American characters. Among them, Orson Welles' Touch of Evil (1959) captures the essence of the border through a noir lens, quite effective in conveying its gritty, ambiguous dynamics (Nericcio 39-80); the movie delivers articulated representations of borderland otherness and its constructs, and it revolves around the clash between a Mexican agent and his American counterpart. Anthony Mann's Border Incident (1949) also focuses on the border and the collaboration between two such characters, whereas Ida Lupino's noir road movie The Hitch-hiker (1953) exploits the trope of border crossing as escape route for a deranged criminal. As the genre reached its apogee in the $50 \mathrm{~s}$, the Mexican film industry was fruitfully producing film noir-or cine negro-as well, reproducing the features distinctive of the US production; the genre counted with renowned época de oro directors such as Julio Bracho, Alejandro Galindo, and Roberto Gavaldón (especially with his recurrent collaborator José Revueltas). It is worth mentioning the occasional production of films with a transnational setting, such as Juan Bustillo Oro's Asesino X (1955), focusing on the noir misadventures of a Mexican man framed for murder in California after serving repeatedly in the US army. Interestingly, the plot facilitates the representation of discriminatory practices toward Mexicans living on US soil. Aside from the occasional-and quite effective-transnational settings, the main cities used as backdrop for noir cinema and literature have been New York, San Francisco, and Los Angeles. The latter functions as a suitable setting for stories characterized by sordid plot developments and compromises, as Los Angeles itself symbolizes the place where dreams can come true and yet, the pursuit of such dreams is often tied to delusion, struggle, and eventual failure. Despite the historical presence of a diverse Latinx population, in film and roman noir Los Angeles rarely endows ethnic characters with articulated agency. Sonambulo moves across the city and through areas that have been consistently populated by Latinx communities such as Whittier, thus enriching the stereotypical noir description of Los Angeles.

If Latinx are invisiblized, the occasional presence of African American tertiary characters usually happens when the white protagonists move within some specific milieus, such as boxing gyms and, more relevantly, nightclubs. Even though the relation between noir ambiance and jazz has consolidated through the years following the apogee of classic film noir-to the point that it has been defined as a 
"perceived collaboration between film noir and jazz" (Butler 2)-it is safe to say that film noir proposed sequences featuring bands playing music suggestive of jazz. As David Butler has underlined, the combination between film noir and jazz is, in fact, quite common in the public imaginary and it has been exploited by the music industry to market jazz recordings, including jazz variations of film noir scores that mostly relied on symphonic soundtracks. Drawing on this perception of jazz performance as evocative of noir ambiance, in the case of music as well Navarro brings forth his own personal taste and connection to a markedly Latinx background, endowing his protagonist with a passion for Afro-Cuban jazz. The strongly emotional quality of noir blends with the choice of music and permeates the sequences in which Sonambulo's memories and nostalgia are constructed. The fundamental role and presence of music is set clear right from the beginning, as Sleep of the Just opens with a city view starring the sign of a club called "Mango Mangue" in the foreground, establishing the main perspective line guiding the reader's gaze (9). From this initial wink at Charlie Parker and Machito's eponymous Afro-Cuban jazz piece (recorded in 1948) to the presence of boleros such as "Piel Canela", Navarro articulates his protagonist's relation with music and mambo dancing throughout the series (Marini). A particularly interesting example is the exploitation of the lyrics of the bolero "Mala Noche" as a diegetic intertextual device descriptive of Sonambulo's mood, bringing together multimodal elements to convey a more nuanced meaning (42). It is worth noting that this device has been exploited by other artists in the comic noir genre, especially later on; for example, it is considered as a distinctive feature of Diaz Canales and Guarnido's Blacksad (Austin).

The most evident element of noir hybridization, though, is the quintessential role of lucha libre, pervasive throughout Navarro's comic book series. Imported by European migrants to North America during the second half of the 19th century, Greco-Roman wrestling evolved into a spectator sport performed especially in the US-Mexico borderlands. In 1933, Mexican entrepreneur Salvador Lutteroth saw a potential in the dynamics intrinsic to such performances and founded the Empresa Mexicana de Lucha Libre, promoting it as a sports entertainment (for a historical overview, see Monroy Olvera and Reducindo Saldivar). The popularity and pervasiveness of it grew rapidly, reaching an apogee in the $50 \mathrm{~s}$ and $60 \mathrm{~s}$. Aside from the actual lucha performances-usually taking place during the weekend in large arenas-recognizable themes and elements peculiar to lucha libre were 
disseminated across the available media. A prolific production of movies and magazines reprising the salient moments of bouts, as well as blends of comics and photo novel, contributed to increasing and feeding the popularity of wrestling.

The flashbacks in the comic-reproducing Sonambulo's wrestling life before the sleep-take place indeed in 1959, whereas the storylines set in the present correspond to the time in which the issues were published. In both cases, the reconstruction of the context is rendered through establishing details, while the protagonist himself and his memories function as a bridge between the two fundamental chronological moments. References to the so-called cine de luchadores are scattered throughout the Sonambulo comic books. Such kind of references often characterizes lucha-inspired comics, together with fragments of storylines reprising lucha tropes, produced by Mexican American creators; among others, it is worth mentioning Rhode Montijo's Pablo's Inferno (2000, \#3), as well as Jason Gonzalez's La Mano del Destino (2011-2018). The strong cultural link that Mexican American communities have maintained with classic Mexican lucha libre has been facilitated by means of televised broadcasting of matches and, in particular, the films produced during its apogee, starring actual luchadores. Most of these films are characterized by a peculiar blend of subgenres, usually verging toward campy horror-in particular revolving around a diverse range of monsters-and science fiction. The cine de luchadores is usually marked by paradigmatic narrative patterns, in which the luchador-hero acts out of the ring for a "good cause". Most often he intervenes to save the main charactersinnocent people, close friends, or acquaintances-from the threats posed by either evil antagonists, classic horror monsters, or extraterrestrial entities. A good example of this kind of films is represented by those in which the protagonist is the legendary luchador El Santo; the performer starred in more than 50 feature films in which he played himself, without ever breaking out of character. The use of a mask is, in fact, the key element structuring a form of kayfabe distinctive to Mexican wrestling. In the beginning, wearing a mask was a mere device to allow defeated luchadores to continue wrestling under a new identity. In the 50s, some of the most legendary luchadores-such as El Santo, Blue Demon, Huracán Ramírez-rose to fame as masked characters, whose articulation revolved around the mask itself. The suspension of disbelief intrinsic to professional wrestling-also called kayfabe-is necessary to support the staged quality of the performances. The audience pretends to believe in the 
genuineness of the show, interacting and directly participating in it, as-borrowing Barthes' words-the very virtue of the spectacle is the theatricality, the mimicry of justice, and the amplification of rhetoric, rather than its realism (Barthes 13-23). In lucha libre, wrestlers not only avoid breaking character during the show, but they also maintain the kayfabe throughout any public appearance; hiding their actual identity behind the mask, wrestlers never step out of the mythic dimension they live in. Sonambulo remains bound to his lucha past and always appears wearing his mask no matter the context (figure 1), reminding of the luchadores' daily life as represented in lucha libre films.

Sonambulo is, in fact, a character built according to the ethos intrinsic to lucha libre in its prime. Aside from resorting to lucha moves whenever he fights ${ }^{4}$, he acts abiding by a clear set of values and beliefs, helping others without any personal benefit or interested goal. Despite embodying the noir private eye archetype "midway between order and crime [...] responsible for himself alone" (Borde and Chaumeton 7), Sonambulo emerges as a positive subject in the otherwise noir-driven contexts and surreal situations he gets entangled in. He usually acts following his own code of conduct and for "the right reasons", seemingly sticking to a lucha ethos remindful of El Santo's filmic stints. Despite his occasional sentimental faltering-often triggered by his memories (see for example the Ghost of a Chance arc)-he doesn't yield to the cynicism or moral quandaries characterizing his antagonists. Sonambulo is "a paladin, our last resort to protect us all from all the terrors of the unknown, as well as the borderland of the subconscious" (Navarro, "Tell Him Your Dreams"). In fact, noir-related obsessions and derangements also emerge through the dreams represented in the comic book series, as an outlet for the subconscious of both Sonambulo's adversaries and himself.

4 In each of the main narrative arcs wrestling sequences are present; it's worth mentioning in particular a fight employing chairs - as it commonly occurs in lucha librein Sleep of the Just (2000, 84-86), as well as a long sequence of wrestling on the ring in Ghost of a Chance (16-19). 
TELL HIM YOUR DREAMS: THE ONEIRIC INTERPRETATION OF NOIR

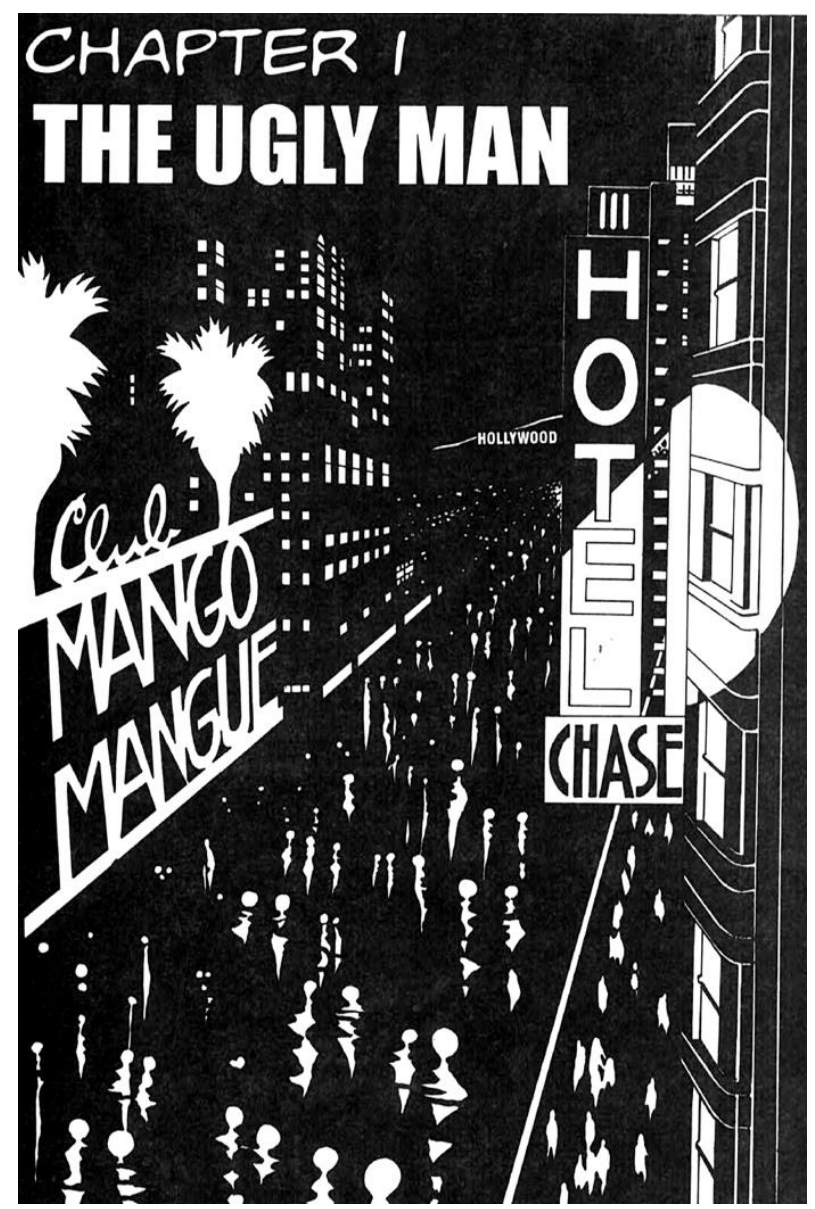

Figure 1 Sleep of the Just. The Collected Case, 9.

The definition of the noir genre is, in itself, somehow problematic to tackle. Deriving from a certain type of hard-boiled literature-facilitated by a growth of criminal fiction in the 20 s and 30 s, fueled by the gloom of the Great Depression-film noir as it is classically intended was produced in Hollywood starting in the early $40 \mathrm{~s}$ through the 50s. The filmographic boundaries of the genre are 
debated according to the stylistic parameters considered; nonetheless, critics have often set them by indicating Boris Ingster's Stranger on the Third Floor (1940) as a first consistent example, and Orson Welles' aforementioned Touch of Evil (1959) as the last noir masterpiece. Film noir is often associated with some visual and narrative key traits which, yet, don't seem enough to define clear genre boundaries. It seems, rather, that noir should be defined as well by its underlying discourse and the representation of society it provides, infused with a modernist spirit (Naremore 40-97).

Aesthetically, film noir is usually characterized by low-key lighting, asymmetric composition, vertiginous angles, oppressive urbanscape settings, and often indistinguishable interiors. The shaping of the genre's mood and atmospheres was possibly inspired by German Expressionism (Vernet 7-12), as well as Surrealism-in particular regarding certain facets that can be connected with Sonambulo's articulation. The link between noir and Surrealism has been highlighted by several scholars and critics, as surrealist cinema defied bourgeois art and lifestyle, de-sublimating everyday life through its dream-related symbolic representations and irrational imagery (Naremore 18). In Navarro's comic book series, the noir mood is set clear from the beginning, as Sleep of the Just opens with a splash page reproducing a busy street seemingly crowded with venues and the renowned "Hollywood" sign landmark in the far background (figure 2). In the following page, paper waste marketing some show lies on the floor, wetting in the rain, throwing the reader right into the tropes characterizing the signification of Los Angeles as a place where hopeful dreams get wasted and the value of many people's life is commodified (for an interesting perspective on the topic, see Silver and Ursini). Noir draws on the contradictory images of Los Angeles in the popular imaginary (Olsin Lent 329-330). If on the one hand the city has been long considered as a land of opportunities - as well as one of the places of the American Dream closest to the southern border-on the other hand it inevitably becomes a place of alienation, due to deracination, unrealistic expectations, and socioeconomic inequality. The weather itself has a recognizable role in the reconstruction of the noir ambiance, as "in the noir city, like the human condition, [weather] fluctuates between extremes" (Christopher 32); characters move through deceptively sunny, scorching hot suburbs and rainy, inclement pursuits in dark urban alleys. In fact, in Navarro's series, Sonambulo participates in frantic pursuits often happening in the pouring rain. Two sequences worth mentioning in this regard are 
found in Sleep of the Just (10-20) and the story "The One That Got Away."

As it happens in film noir, the nocturnal setting is prevalent in Sonambulo and supported by the fact that the protagonist is not able to sleep since he woke up in the present. Besides, he deals with shady small-time criminals, as well as supernatural-driven situations, and therefore often acts at night. Noir exploits the metaphorical darkness inherent to the night itself; aside from prevalent visual stylizations, the genre usually brings forth a representation of relations within society that comes across as pessimistic, often cynical and subjected to personal interest. Noir characters seem to move in an ambiguous dimension, where the storyline follows changing power relations, nonlinear narratives, a certain eroticism usually confined to dialogue and visual implication, and often a disconcerting unfolding of the action. Moral boundaries often blur, according to the characters' needs, impulses, and desires. The psychology of crime intrinsic to film noir sees the concepts of good and evil merging and overlapping, inevitably eliciting contradictory emotions in the viewer. There is an underlying description of otherness in film noir, an implicit crossing of boundaries, whether physical-as in going to "darker" places within the urban fabric-or metaphorical, breaking conventional moral codes. The diegetic articulation of unlawful activities, shocking violence, sordid behaviors, unrepentant corruption, contributes to creating an unsettling sense of ambivalent alienation. Dreamlike-or rather, nightmare-like-is the atmosphere common to many a film noir. The viewer is disoriented by the uncertainty of the motives eluding conventional frames of reference (Borde and Chaumeton 11) and constructing the oneiric quality of the genre. As crime fiction writer James Ellroy has pointed out, film noir is "photographed to give you a heightened sense of displacement" so that as a spectator "you're inside somebody's dream, or somebody's nightmare" (in Kuperberg and Kuperberg). Ellroy maintains that the fascination with both roman and film noir stems from the entanglements and circumstances that cause the protagonists' lives to go awry and things inevitably ending badly_-"the big fuck up" as he calls it (ibid). In some cases, overwhelming dream sequences actually appear in film noir, as it happens in the aforementioned Stranger On the Third Floor. In many a situation, the spectator is faced with sequences in which the boundary between dream and fictional reality is unclear. Especially when they serve the staging of the characters' displacements-whether to escape or chase someone-noir directors exploited a sense of hallucinatory 
drive pushing them. In Sleep of the Just, the city melts noir and oneiric dimension as the transition between a dream and reality gives the reader a glimpse of some Antonio Sant'Elia-esque architectural renditions of a futurist world, characterized by machine-like superstructures (36).

In most narrative sequences, Navarro evidently favors the oneiric quality of noir rather than the sense of malaise often intrinsic to the genre, while retaining its nocturnal atmospheres. The evocation of angst and unease relies on horror elements rather than the noir ambiance itself. The artist's take on the oneiric dimension overlaps noir ambiance and a filmic magic realism-also defined as fantarealismo-remindful of Fellini's eeriest sequences, with their bizarre and yet congruent take on reality and nostalgia. Navarro indeed draws his dream related inspiration from several sources. If on the one hand his passion for cinema led him to tap into influential works such as Fellini's ${ }^{5}$, on the other hand his own sensibilities as an artist definitely stem from his cultural heritage as well. As it will be analyzed further on, the Mexican American folktale tradition comes with an intrinsic sense of supernatural magic, often characterized by a blur between dream and reality indeed. Fellini's influence can be traced through the most visionary Sonambulo sequences, as well as in a peculiar sense of reality Navarro's character seems to live by. In films such as $81 / 2$ (1963), the Fellinian protagonist-getting in touch with his feelings and dreams-incurs in moments of clarity and irony on the reality of life; a stance assumed by Sonambulo as well, possibly thanks to his belonging to another era and yet moving shrewdly in the present.

Aside from a deep fascination and interest in dreams, their articulation and representation, Navarro humbly shares with Fellini a versatile approach to artistic expression. A keen comic books and strips reader, the Italian director himself was a cartoonist (in particular at the beginning of his career in the 40s), as well as-from the 60s till the summer of 1990-a steady transcriber of his own dreams, mostly by means of colorful illustrations (collected in Fellini, Il Libro dei Sogni). Fellini's later incursions into ways of exploiting the comic medium were marked, as well, by a strong connection with oneiric and fantastic moods, almost supernatural and yet realistic. It is worth mentioning his collaboration with artist Milo Manara, as in Viaggio a Tulum (1986) the protagonists set off to undertake a real-life

\footnotetext{
${ }^{5}$ Rafael Navarro. Personal conversation with the author, August 2, 2020.
} 
quest, extracting useful details about reality from dream sequences. The director underlined on many an occasion the strict correlation between his cinema and comics, identifying the latter as his main matrix of inspiration (Fellini, "Interview"). Besides the evident mutual influence on diegetic construction and the framing choices made by both comics and film creators, he recognized the role of comics in giving rise-by means of stimulating imagination and humor-to a critical approach to reality and social conventions (ibid.). Thereforedespite the apparently oxymoronic nature of the notion of "oneiric realism"- the dream becomes, indeed, a mechanism to bare the actual face of reality and, at the same time, lucidly highlighting its absurdity and relativity.

Dreams are primarily visual experiences and so are comics. Allowing the exploitation of both verbal and visual elements, the combinatory possibilities offered by comics facilitate the diegetic insertion of dream sequences, as well as the exploitation of the bizarre imagery peculiar to dreaming. Likewise, a disruptive play with the sequentiality of the medium can enhance the insertion of dreamrelated content (Barrett and McNamara 146). Aside from comic strips such as pioneering McKay's Dreams of the Rarebit Fiend (1904-1913) or Little Nemo in Slumberland (1905-1914) - as well as Rick Veitch's reprise of the former as comic books in the 90s (1994-2016)-some relevant overtly dream-based comics have been created. In this regard, it is necessary to mention at least the Sandman saga written by Neil Gaiman (1989-1996) for its take on the representation of dreams and dreamworlds, as well as its popularity. More in general, the oneiric dimension has fascinated comic creators, even leading to the publication of eerie, investigation-based series such as Kirby and Simon's The Strange World of Your Dreams (1952-1953), in which various characters delve into the relation between reality and dreams, trying to trace connections and resolve mysteries through the interpretation of dreams. Through his characters, Navarro becomes the narrator of the oneiric dimension that lies behind people's attitudes and actions, translating their subconscious into images; his protagonist delves into people's dreams to see the truth behind words. Nonetheless, Sonambulo remains within its peculiar cross-genre, without yielding to fantasy, sci-fi, or dystopian subgenres.

Given how dreams exacerbate the anguish intrinsic to noir narrative, Navarro inserts often disturbing dream sequences in key moments in which the protagonist faces his criminal antagonists. The first sequence of this kind appears in Sleep of the Just (16-19), 
introducing as well Sonambulo's trademark request "tell me your dreams". The visual construction of the following page reminds of Escher's stark graphic effects (17) playing with the black and white. Then, the dream recreation slides into a diegetic sequence (18-19) almost remindful of Japanese yōkai visuals. In "Surrealistic Pillowtalk"-Navarro's story in Masks of Sonambulo (2-7)-the artist has condensed Sonambulo's relation with the oneiric dimension, as the reader sees him "visiting" and coping with a series of dreams while musing on the connection people have with them, his internal monologue caught by means of thought captions. The artist evidently exploits the theatrical quality intrinsic to dreams, conveying anguish, memories, and expressions of the unconscious. Sonambulo accesses the supernatural dimension through dreams, outlining an uncanny zone-related to his deep sleep-between the real world and the unreal.

As commented above with regard to Fellini's dream transpositions, the myth of the director as a magically vaticinating character is deceptive-as well as a possible over-interpretation-and, at the same time, proves correct in his foretelling narratives (Ceccarelli 17). Sonambulo himself reads people's dreams to extrapolate details useful to unravel the case he's working on. The dream sequences might appear as hallucinatory and confused, yet they tend to carry images useful to the interpretation of reality, pointing the protagonist's investigations in the right direction.

\section{TRANSNATIONAL FUSION OF NOIR AND FOLKTALE HORROR}

The exploitation of horror tropes and moods in a noir narrative is neither unusual nor new, given that horror films definitely played a role in the development of film noir ambiance (Borde and Chaumeton 25). Navarro's work, though, blends in steadily the presence of the oneiric dimension, as well as supernatural elements that belong to the Mexican American cultural heritage, drawing on Mexican folktale and Pre-Hispanic myths.

Both horror and noir stem from German Expressionism-both stylistically and in the reconstruction of dark, doom-infused moodsand, especially in the $40 \mathrm{~s}$, in some films the two genres seemed to overlap quite easily and it has proven difficult for critics to define them accordingly (Hutchings 111-114). Furthermore, as Peter Hutchings has underlined, the 30s American horror can be viewed as an evolutionary link between pre-30s expressionist films and 40s film 
noir. For his part, Marc Vernet has pointed out that many noir creators did not have connections with expressionist productions, and thus prefers to draw the link between American gothic film and film noir (Vernet 11-12). Aside from possible debates on the actual roots of the noir genre, it is safe to say that the upsetting, alienating, and psychologically induced sensationalism marking many a noir movie brings them close to horror renditions. The boundary between horror and noir blurs, in particular when elements perceived as supernatural or generally uncanny come into play and trouble the protagonists' lives. It is worth mentioning the existence of a few films in which noir and horror tropes and stylizations openly blend; among them, John Parker's Dementia (1955, later re-released as Daughter of Horror) also includes the theme of nightmares and delves into the protagonist's paranoia and troubled ambiguity.

Aside from the aforementioned Mexican production of film noir, the history of Mexican films inspired by supernatural themes is rather rich and often fueled by the reprise of supernatural folktales, tropes, myths, and superstitions. In the $30 \mathrm{~s}$, the horror genre began to develop and flourished throughout the 40s, usually exploiting wellknown supernatural archetypes such as vampires and werewolves, as well as local legends such as La Llorona. Without delving into the Mexican folklore related to, or stemming from, its peculiar cultural and anthropological relation with death-on which it is worth recommending Matos Moctezuma, as well as the research and bibliographic work by Lomnitz-it is relevant to note that most folktale paradigms exploited by Mexican horror are crucially concerned with death, ghost-like entities, and afterlife curses. The cine de luchadores itself-especially in the 50s and 60s-intersected with horror and classic monster archetypes, although in a campier way, far from the oppressive, anguish-ridden moods delivered by film noir (for a study on the specific topic, see Cotter). Lucha libre tropes were pervasive across genres and would be exploited in many films in which some sort of powerful, fantastic hero was involved. Thus, the construction of antagonists would often verge toward exaggerated villain figures, whose evil doings involved meddling with monster creatures and unrealistic horrific plots.

Navarro's hybridized noir draws on these cinematic inspirations, delivering a peculiar blend of horror-noir moods. Entangled storylines and the strange, alienating unfolding of the action meet supernatural archetypes, at times verging on a campy atmosphere facilitated by Sonambulo's own disenchanted irony. Aside 
from the evident influence of Mexican American cultural heritage in the shaping of the horrific components, the protagonist's encounters with supernatural beings are partially connected to the geographical setting, as his action physically oscillates between a more noir-infused Los Angeles urbanscape and horror-driven Mexican sceneries. In this regard, border-crossing acquires an additional significance, as it embodies the bridge between a reality anchored in the present-in which supernatural elements are strictly related to the oneiric dimension or to the doings of local cults - and a world of the origins, where supernatural elements seem to intersect with everyday life. The insertion of purely horror elements in Sonambulo's cross-border stints becomes representative of the transnational and transcultural boundary, as a diegetic embodiment of the problematic existence and dynamics of the US-Mexico border itself.

Killing cults, often dedicated to supernatural rites and human sacrifice, have been a staple subject for many a horror movie. Among films worth mentioning, in Lewton's The Seventh Victim (1943) horror and noir sensibilities and stylizations melt, delivering a story in which a cult is involved. Likewise, the main storyline in Sonambulo's Sleep of the Just arc is a crime case strictly related to a fictional satanic cult, inspired by the artist's own childhood memories of rumors about the existence of cult meetings on the Whittier hills in the $70 \mathrm{~s}^{6}$. The narcissistic cult leader Eugene is an antagonistic character that will reappear later on at the beginning of the Mexican Stand-Off arc-again performing a satanic rite-as he repeatedly manages to escape Sonambulo's chase.

Drawing on the idea that the nocturnal urban noir setting can be interpreted as a representation of the masculine unconscious (Naremore 43), Sonambulo's night is often a moment in which the private eye delves into his memories, hallucinatory dreams, and fears. Outside of the oneiric dimension, his nights are populated by the protagonist's encounters with male real-life criminals and ghostly beautiful women. The collection of short stories Sonambulo's Strange Tales (2000) is characterized by phantasmal, nocturnal moods and it represents a dive straight into Mexican folktale. The volume starts with "The Old Country" (1-10), a story in which the protagonist has a brief encounter with La Llorona, a Latinx legendary figure who is believed to have drowned her own sons and therefore is forced to wander in desperation. In Mexico, the legend is rooted in Pre-Hispanic myths

${ }^{6}$ Rafael Navarro. Personal conversation with the author, August 2, 2020. 
often linked to female divinities such as Cihuacóatl—among which the version identifying the ghost with the cihuateteo, the Mexica spirits of women who died in childbirth-or Tenpecutli, whose diegetic background is very close to that of La Llorona especially in the Xochimilco area (Portal and Salles 63). The figure has also been intersected with the history of the conquest: the crying woman, mother of mestizo children, has metaphorically embodied the defeated indigenous people. Many authors have written comprehensively about it, but it is worth recalling Gloria Anzaldúa's Chicana perspective on the subject $(1987,35-38)$. La Llorona as horrific character and the variations of the related legend have been the subject of numerous movies. Notably, Ramón Peón's La Llorona (1933) is often considered as the first Mexican horror film; many have followed, including Rafael Baledón's gothic horror version La Maldición de la Llorona (1963), as well as a movie starring the aforementioned luchador El Santo, La Venganza de la Llorona (1974). The ghost appears at Sonambulo's office late at night as a fascinating client, apparently willing to hire the detective to find her missing children, whom, nonetheless, she assumes dead. Through a flashback-drawn in pencil, contrasting with the stark black inking characterizing the comic-Sonambulo recalls his brother's disappearance, which seemed connected to the presence of a mysterious woman. As the conversation between the two progresses, it turns out that the woman is, in fact, La Llorona. Her transformation-as well as her attack on Sonambulo (8-10) to strip him of his mask-is unexpected and shocking, as her true aspect is ghastly and horrific, thereby conveying the torment and pointless repentance she has been haunted by.

The second segment of the Strange Tales book is an illustrated short story set in Mexico, "A Family Matter" (11-26), in which Sonambulo is hired to solve a mystery surrounding yet another beautiful woman that leads him to cross the US-Mexico border. Once again, appearance is deceitful and the woman reveals herself as a monstrous being, possessed by desire. In the last story "En Calavera..." (27-42), Navarro introduces themes related to the Mexican celebration of the Dia de Muertos, blending it with a classic exploitation of the zombie paradigm. In this case set in Norther Mexico-as he crossed the border to assist to the celebrations with his loyal assistant Xochi-the private eye faces the evil doings of a local curandera, who's trying to free her subordinate living dead. The curandera/o is a central figure in Mexican-and thus, Mexican American-belief, as s/he is the beholder of botanical knowledge and related folkways, employed in 
benefit of the community. The difference between curanderos and brujos-who allegedly exert black magic to harm-is relevant, although it can be blurry and often overlooked by observers external to the community itself ${ }^{7}$. In the comic book, the woman regrets having exploited her powers in her own interest, and she seeks redemption by breaking the bounds with the undead beings she created. The choice of articulating a zombie narrative is interesting, as at the time Navarro created it in the late 90s, the revival of the undead archetype in fiction had not yet developed. A keen fan of Romero's Night of the Living Dead (1968) and similar horror tropes, the artist intentionally brought into play the archetype ${ }^{8}$ with an ironic element of surprise to it. The undead at first seem to be maliciously attacking people, but then it turns out that they have been freed from the magical yoke and they mean no harm to anyone. Despite being recurrent and successful in Western popular culture, the zombie genre had seen a decline in the late 80 s, only to make an acclaimed comeback in the early 2000 s across media-notably with the comic book series The Walking Dead (2003-2019). Right before the revival kicked in, another rare appearance of the undead in comic books could be represented by The Goon, which was constructed by its creator Eric Powell in the late 90s and regularly published by Dark Horse Comics since 2003. Powell's creation also deals with zombies and other supernatural entities, occasionally blending horror with crime and mystery-infused storylines; it is worth mentioning the special 3-issue miniseries The Goon Noir (2006), an anthology of noir short stories published in black and white in which various creators collaborated.

In Sonambulo's Ghost of a Chance (2002), the narrative arc ends with a long lucha sequence set within the oneiric dimension the private eye occasionally moves in (32-43). In this case, the supernatural pivot is embodied by a horrific Mictlantecuhtli-the main of the two deities governing over the Aztec underworld or Mictlán (Matos Moctezuma 72-82)-whose portrayal recalls indeed certain Mexica representations in particular. In his nightmare, Sonambulo finds himself in the land of the dead challenged by a jaguar warrior on behalf of the powerful god, outraged by the man's defiance. In the Aztec mythology, the feline is a symbol of power linked to the supreme

\footnotetext{
7 A rather good example of the fictional representation of this kind of practices and related dynamics can be found in the renowned novel Bless Me, Ultima (1972) by Chicanx author Rudolfo Anaya, set in the US borderlands.

${ }^{8}$ Rafael Navarro. Personal conversation with the author, August 2, 2020.
} 
god Tezcatlipoca as his nahual, or animal shape (Olivier 100). The jaguar myth of Tepeyóllotl (literally "heart of the mountain") is pervasive in codices, usually related to the night and the trope represented by the cave, in particular as way to access the underworld. In the period of flourishing shortly before the conquest, warriors wearing jaguar-stylized outfits formed a specific elite section of the Mexica army; in fact, Sonambulo and the warrior face one another wielding the combination of chimalli shield and macuahuitl (traditionally built as a wooden club with obsidian blades). As the protagonist wins the fight, Mictlantecuhtli is impressed by his courage and determination, sparing his life. The end of the supernatural wrestling sequence holds a hinted reference to legendary luchador El Santo as well.

The main storyline in the Mexican Stand-off arc (2004-2006) is set in Mexico and revolves around a supernatural plot, connecting with Mexican history as well. The story starts off right in the middle of the action: Sonambulo and his assistant Xochi are bound to face Eugene and his satanic cult again, given how they tracked him all the way to New Jersey. Unleashing a dragon-looking demon, their recurring antagonist manages to escape; nonetheless, a new character is introduced right away (13), bringing back Sonambulo's past life. The detective is bound to cross to Mexico in order to help an old friend of his, a professor in Pre-Hispanic history facing a distressing supernatural circumstance. In this case, Navarro plays with Mexican archeological history in order to serve the creation of a peculiar character, whose work is meant to be on a blurred line between facts and supernatural dimensions. Professor Girafales is presented as a genius mind, to the point he allegedly deciphered "the complete Aztec and Mayan alphabet in the 1940's" (19), an evident historical and linguistic fabrication supporting the reach of his fictional experience. The plot revolves around a legend of two conflictive brothers who are in love with the same woman, whom they killed by accident during a duel. Later on, they fought on antagonistic sides during the Revolution and killed each other on the battlefield. The story is enriched by long sequences of supernatural action, until the unresolved conflict between the two spirits eventually reaches an end, thanks to the intervention of the woman's ghost. 


\section{CONCLUSIONS}

Supernatural entities strictly intertwined with Mexican traditional folklore, detailed noir ambiance, lucha tropes, all represent the distinctive elements that unfold and deepen throughout Sonambulo's publication history. Navarro provides a complex, articulated expression of a Mexican American identity that comes across as unrestrained, unwilling to be confined in either stereotypes or related paradigms. The artist's take on his own cultural heritage challenges and at the same time draws on traditional Chicanx archetypes, creating a unique cross-genre narrative that reveals the multifaceted nature of Mexican American creation. The inherent transnational nature of Sonambulo reveals the inevitable connections to the "other side", whether as cross-border space, Latinx third space within the US dominant culture, or space of the subconscious. Its drift toward the oneiric dimension suggests, indeed, the existence of heterotopic spaces straddling the existing boundaries. In its own distinctive, highly hybridized way, Sonambulo creates a bridge across the US-Mexico border; a frontier that is, evidently, both material and metaphorical, representative of the social and ethnic boundaries internal to-and deeply rooted in-US society. Navarro's work represents and celebrates the diversity exiting within the Mexican American community, eluding predetermined categories and at the same time delivering a comic book that is profoundly connected to his Chicanx heritage.

\section{WORKS CITED}

ALDAMA, Frederick Luis. Your Brain on Latino Comics. University of Texas Press, 2009.

---, editor. Tales from la Vida: A Latinx Comics Anthology. OSU Press, 2018.

ANZALDÚA, Gloria. Borderlands/La Frontera. Spinsters, 1987.

AUSTIN, Hailey J. "That Old Black Magic': Noir and Music in Juan Diaz Canales and Juanjo Guarnido's Blacksad." The Comics Grid: Journal of Comics Scholarship, vol. 9, no. 1, 2019, p.12. DOI: http://doi.org/10.16995/cg.156

BARRETT, Deirdre and Patrick McNamara. Encyclopedia of Sleep and Dreams: The Evolution, Function, Nature, and Mysteries of Slumber, Volume 1. ABC-Clio, 2012. 
BARTHES, Roland. Mythologies. Éditions du Seuil, 1957.

BORDE, Raymond and Etienne Chaumeton. A panorama of American film noir (1941-1953). 1955. Translated by Paul Hammond. City Lights Books, 2002.

BUTLER, David. Jazz Noir: Listening to Music from Phantom Lady to The Last Seduction. Greenwood Publishing Group, 2002.

CECCARELLI, Filippo. "I Sogni Politici di Fellini." In Federico Fellini, Il Libro dei Sogni, edited by Sergio Toffetti, Rizzoli, 2019, pp. 17-20.

CHRISTOPHER, Nicholas. Somewhere in the Night: Film Noir and the American City. Revised ed., Shoemaker \& Hoard, 2006.

COTTER, Robert Michael. The Mexican Masked Wrestler and Monster Filmography. McFarland, 2005.

FELLINI, Federico. Interview by Renato Pallavicini. L’Unità, July 26, 1992.

---. Il Libro dei Sogni, edited by Sergio Toffetti. Revised ed., Rizzoli, 2019.

FLORY, Dan. Philosophy, Black Film, Film Noir. Penn State University Press, 2008.

GARCÍA, Enrique. The Hernandez Brothers: Love, Rockets, and Alternative Comics. University of Pittsburgh Press, 2017.

HUTCHINGS, Peter. "Film Noir and Horror." A Companion to Film Noir, edited by Andre Spicer and Helen Henson. Wiley-Blackwell, 2013, pp. 111124.

KUPERBERG, Clara and Julia Kuperberg, directors. Los Angeles: Cité du Film Noir. Wichita Films, 2015.

LOMNITZ, Claudio. Death and the Idea of Mexico. Zone Books, 2006.

LOTT, Eric. 1997. "The Whiteness of Film Noir.” American Literary History Vol. 9, No. 3 (Autumn, 1997), pp. 542-566

MARINI, Anna Marta. 2020. "Mala Noche: The Use of Music Throughout the Sonambulo Comic Book Series.” PopMeC Research blog. Published August 10, 2020.

MATOS MOCTEZUMA, Eduardo. Muerte a Filo de Obsidiana. Los Nahuas Frente a la Muerte. 1975. Fondo de Cultura Económica, 2016.

MERINO, Ana. "The Bros. Hernandez: A Latin Presence in Alternative U.S. Comics". Redrawing The Nation. New Directions in Latino American Cultures, edited by Hector Fernández L’Hoeste and Jorge Poblete. Palgrave Macmillan, 2009, pp. 251-269. 
MONROY OLVERA, Hugo and Miguel Reducindo Saldivar. Lucha Libre 85 Años. Am Editores, 2017.

NAREMORE, James. More than Night: Film Noir in Its Contexts, Updated and Expanded Edition. University of California Press, 2008.

NAVARRO, Rafael. Interview. In Frederick Luis Aldama, Your Brain on Latino Comics, 223-233. University of Texas Press, 2009.

---. "Mi voz." In Tales from la Vida: A Latinx Comic Anthology, edited by Frederick Luis Aldama. OSU Press, 2018, pp. 154-155.

---. "Tell Him Your Dreams: Sonambulo and the Oneiric Lucha-Noir Mood." Interview with Anna Marta Marini. PopMeC Research Blog. Published July 1, 2020. popmec.hypotheses.org/2618.

NERICCIO, William A. Tex[t]-Mex: Seductive Allucinations of the "Mexican" in America. University of Texas Press, 2007.

OLIVIER, Guilhem. “Tepeyóllotl, 'Corazón de la Montaña' y 'Señor del Eco': El Dios Jaguar de los Antiguos Mexicanos." Estudios de Cultura Náhuatl, no.28, 1998, pp. 99-141.

OLSIN LENT, Tina. "The Dark Side of the Dream: The Image of Los Angeles in Film Noir." Historical Society of Southern California, vol. 69, no. 4, 1987, pp. 329-348.

PORTAL, María Ana, and Vania SALLES. "La tradición oral y la construcción de una figura moderna del mundo en Tlalpan y Xochimilco." Alteridades, vol. 8, no. 15, 1998, pp. 57-65.

SILVER, Alain, and James Ursini. LA Noir: The City as Character. Santa Monica Press, 2005.

VERNET, Marc. "Film Noir on the Verge of Doom." Shades of Noir: A Reader, edited by Joan Copjec. Verso, 1993, pp. 1-32.

\section{Comic books cited}

BRUBAKER, Ed (w) and Sean PHILLIPS (a). The Fade Out. Portland, OR: Image Comics, 2014-2016.

CHAYKIN, Howard. Black Kiss. Toronto: Vortex Comics, 1988-1989.

DÍAZ CANALES, Juan (w) and Juanjo Guarnido (a). Blacksad. Paris: Dargaud, 2001-2013.

EISNER, Will. Will Eisner's The Spirit Archive. Collected edition. Burbank, CA: DC Comics, 2009 [1940]. 
FELLINI, Federico (w) and Milo Manara (a). Viaggio a Tulum. 1986. Rizzoli, 1990.

GONZALEZ, Jason. La Mano del Destino Collected Edition. Castle\&Key Publications, TBC 2020.

HERNANDEZ, Javier. El Muerto: The Aztec Zombie. Los Comex, 1998-ongoing.

KIRBY, Jack, et al. The Strange World of Your Dreams. \#1-4. Crestwood Publications (Prize), 1952-1953.

KIRKMAN, Robert (w) and Tony Moore (a). The Walking Dead. Portland, OR: Image Comics, 2003-2019.

MILLER, Frank. Sin City. Milwaukie, OR: Dark Horse Comics, 1991-2000.

MONTIJO, Rhode. Pablo's Inferno. \#1-5. Abismo, 2000.

NAVARRO, Rafael. Sonambulo: Ghost of a Chance. Ninth Circle Studios, 2002.

---. Sonambulo Lives! Ninth Circle Studios, 2009.

---. Sonambulo: Mexican Stand-Off. \#1-3. Ninth Circle Studios, 2004-2006.

---. Sonambulo: Sleep of the Just. \#1-3. Ninth Circle Studios, 1996.

---. Sonambulo: Sleep of the Just. The Collected Case. Ninth Circle Studios, 2001.

---. Sonambulo's Strange Tales. La Habra, CA: Ninth Circle Studios, 2000.

---. "The One That Got Away." Hot Mexican Love Comics vol. 3, 2006, p.6.

NAVARRO, Rafael et al. Masks of Sonambulo. Ninth Circle Studios, 2003.

SÁNCHEZ ABULÍ, Enrique (w) and Jordi Bernet (a). Torpedo 1936. Collected edition, vol. 1-5. Grenoble: Glénat, 2004 [1981-2000]. 